UDC $622.765-344$

\title{
尾去沢鉱山における酸化鉛鉱の浮選
}

正会員白井美 夫*

\section{The Flotation for Oxidized Lead Minerals at Osarizawa Mine}

Yoshio USUI

The flotation methods for oxidized lead minerals, such as anglesite, turnish galena, beaverite, were investigated by three methods mentioned below. Comparing these methods by laboratory studies, following results were obtained.

1) By the soap flotation method, although the cost is low, the lead recovery is very low and the primary slime cannot be treated.

2) In the sulfidizing method using sodium sulphide and sodium phosphate dibasic, the lead recovery is satisfactory but the reagent cost is high.

3) In the modified method, using methyl xanthate and sodium phosphate dibasic, the lead recovery is quite satisfactory and the cost is lower than the sulfidizing method.

Following the third method, our plant operation has been very satisfactory.

\section{1. 緒}

\section{言}

酸化鉛鉱の浮選には次の方法が考えられる

1）石け儿浮選法 分子の無極部分の大きい捕収剂 (主としてオレイン酸およびそのナトリウム塩が用いら れる）を鈗石分子に吸着させて浮選する方法。

2）硫化法 酸化鉛鉱の表面に硫黄イオンを吸着させ て表面の性質を硫化鉱と同様の性質に変化させて後, 硫 化浮選に用いられる捕収剤を吸着させて浮選する方法。

3）直接浮選法 普通の捕収剂より強い踈水性の被膜 で酸化鉛鉣物の表面を被らことが出来る捕収剤で直接浮 選を行なら方法。

4）ザンセート類による活性浮選法 ザンセート類を 酸化鉛鉱物の表面に吸着させて $\mathrm{Pb}$ - ザンセートとして 柾水性にした後, 普通用いられる捕收剤で浮選を行なう 方法。

酸化鉛鉣の浮選は硫化鉱の浮選に比して面倒である。 その理由は脈石が軟かいためにスライムが多く，また 風化されて可溶性塩ができ易く，酸化鉛鉱の表面は脈石 と同様被濡性を持つているためである。尾去沢産の酸化 鉛鉱は 70 80\% が非硫化鉛として分析され，その大部 分は硫酸鉛鈗である。硫化鉛として分析されるものの中 には方鉛鉱の外にビーバーライトも含有されている。

\section{2. 石けん浮選，比重選鉱法による操業}

当所では粗鉣を水洗して一次スライムを除いて石けん 浮選法で,一次スライムは比選法で操業を行なつていた。 選鉙成績は第 1〜2 表の通りである。

*三蓤金属鉣業株式会社尾去沢鉣業所選鉱課
第 1 表 石け九浮選の選鉱成績(昭和 34 年 4 月〜 35年 3 月)

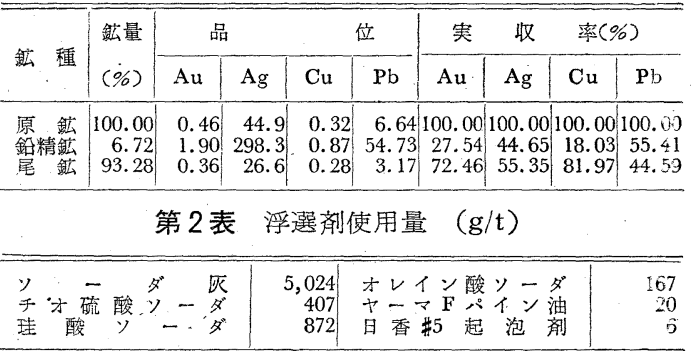

一次スライムの量は原鉣の約 13\% であるが，その品 位は原鉱品位の約 1.3 倍で $\mathrm{Pb}$ 分布率は約 $17 \%$ であ る。一次スライムの $\mathrm{Pb}$ 実収率は約 $17 \%$, 浮選 $\mathrm{Pb}$ 䒠 収率梳約 $52 \%$ ，手選・ジツガー精鈗を合わせた $\mathrm{Pb}$ 宾 收率合計約 $55 \%$ である。原鉱中に含有される $\mathrm{Au}$ ， $\mathrm{Ag}, \mathrm{Cu}$ を回收する目的で石けん浮選の前に硫化物浮選 を試みたが，硫化物浮選でハイヤーザンセートを多量に 使わないと硫化物の実收率は向上しないが，200g/t添加 すると石けん浮選で $\mathrm{Pb}$ 実收率が低下するのでこの試騟 は中止した。

\section{3. 硫化法による浮選試験}

通常のザンセート浮選で硫化物を採取した後，酸化鉛 鉱の浮選を行なつた。ソーダ死で $\mathrm{pH}$ 調節し硫化ソー ダで硫化した後，ハイヤーザンセートを捕収剂として浮 選試験を行なつたが実収率は悪かつた。捕収剤として A.C.C. のエロフロート \#404 および \#242 を用いると 実収率は向上したが浮選剤の費用が高く，採算上不利で あつた。第二燐酸ソーダを併用すると浮選剂の添加量が 
第 5 表 原 鉱 の 種 類

\begin{tabular}{|c|c|c|c|c|c|c|c|c|c|c|c|c|c|}
\hline & \multirow{2}{*}{ 鉣 } & \multirow{2}{*}{\multicolumn{2}{|c|}{ 種 }} & \multirow[t]{2}{*}{ 鉣 } & \multirow[t]{2}{*}{ 量 } & \multicolumn{2}{|c|}{ 品 } & \multicolumn{2}{|c|}{ 位(\%) } & \multicolumn{2}{|r|}{ 有 } & \multicolumn{2}{|c|}{ 率(\%) } \\
\hline & & & & & & total $\mathrm{Pb}$ & $\mathrm{PbS}$ & $\mathrm{PbO}$ & $\mathrm{Cu}$ & total $\mathrm{Pb}$ & $\mathrm{PbS}$ & $\mathrm{PbO}$ & $\mathrm{Cu}$ \\
\hline 原 & $\begin{array}{l}\text { 次 } \\
\text { 級 } \\
\text { 次 } \\
\text { 級 }\end{array}$ & $\begin{array}{l}x_{\text {機 }} \\
x_{\text {機 }} \\
\end{array}$ & 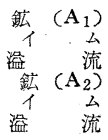 & $\begin{array}{l}565.0 \\
181.0 \\
384.0 \\
522.0 \\
16.0 \\
356.0\end{array}$ & \begin{tabular}{r|r}
100.00 \\
32.04 \\
67.96 \\
100.00 \\
31.80 \\
68.20
\end{tabular} & $\begin{array}{l}5.29 \\
8.74 \\
3.66 \\
4.65 \\
7.54 \\
3.30\end{array}$ & $\begin{array}{l}0.92 \\
1.33 \\
0.72 \\
0.84 \\
1.12 \\
0.71\end{array}$ & $\begin{array}{l}4.37 \\
7.41 \\
2.94 \\
3.81 \\
6.42 \\
2.59\end{array}$ & \begin{tabular}{l|}
0.47 \\
0.58 \\
0.42 \\
0.54 \\
0.70 \\
0.46
\end{tabular} & \begin{tabular}{r|}
100.00 \\
52.95 \\
47.05 \\
100.00 \\
51.58 \\
48.42
\end{tabular} & \begin{tabular}{r|}
100.00 \\
46.54 \\
53.46 \\
100.00 \\
42.38 \\
57.62
\end{tabular} & \begin{tabular}{r|}
100.00 \\
54.30 \\
45.70 \\
100.00 \\
53.61 \\
46.39
\end{tabular} & $\begin{array}{r}100.00 \\
41.51 \\
58.49 \\
100.00 \\
41.51 \\
58.49\end{array}$ \\
\hline
\end{tabular}

第6表 分散分析 の 結果 の総括表

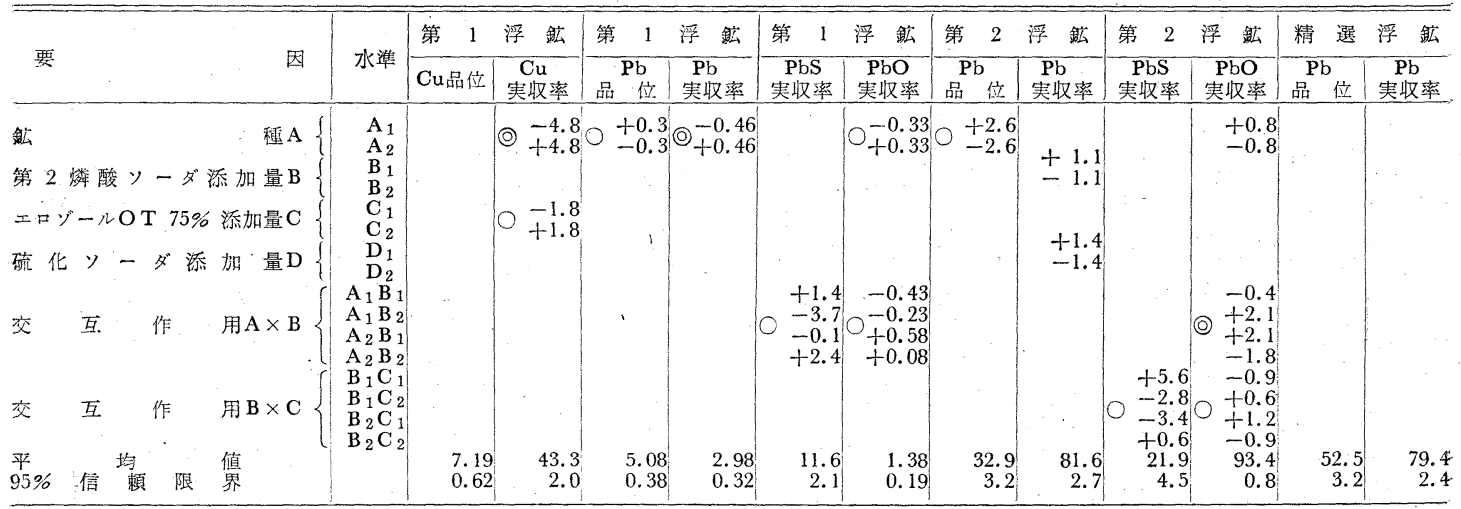

備考：は危険率 $1 \%$ ，○虫危険率 $5 \%$ で有意。

1/3程度に減少したうえ試験の成績も改善された。一次ス ライムを別処理した場合と混合処理した場合との比較を したが成績には差がなかつた。一次スライムを混合して 行なつた試験の一例を次に記載する。

原鉱サンプルを $2,000 \mathrm{cc}$ 容量のデンバー浮選試験機 に移しソーダ灰 $4,000 \mathrm{~g} / \mathrm{t}$ ，第二橉酸ソーダ $2,000 \sim 3$, $000 \mathrm{~g} / \mathrm{t} ，$ エロゾール OT 75\% を 0 20g/t それぞれ添 加して $5 \mathrm{~min}$ 予備攪汼を行ない $(\mathrm{pH} 8.0$ 〜 8.5) エチル ザンセート $100 \mathrm{~g} / \mathrm{t}$ ，日香パイン 7 号 $50 \mathrm{~g} / \mathrm{t}$ 添加して 5 min フロスを採取して第1浮鉣 (銅精鉣) とした。
硫化ソーダ $2,000 \sim 3,000 \mathrm{~g} / \mathrm{t}$ ，エロフロート $90 \mathrm{~g} / \mathrm{t} ，$ エロフロート\#242 $50 \mathrm{~g} / \mathrm{t}$ 添加して $20 \mathrm{~min}$ 間 フロスを採取して第 2 浮鈗とした。第 2 浮鉣はエロフロ 一ト $\# 404$ を $20 \mathrm{~g} / \mathrm{t}$, 日香パイン 7 号を $40 \mathrm{~g} / \mathrm{t}$ 添加して 精選した。

実験の計画は第 3〜4 表に，原鉣の組成は第 5 表に， 直交配列表を利用して計画的に実験を行なつて得られた データについて通常行われている分散分析を行なつて要 因効果の分離をしてその結果を要約して第 6 表に示して ある。浮選試験の結果より推定した選鉱成績を第 7〜8 表
第 3 表 実験の計画 $\left(\mathrm{L}_{8} 2^{7}\right)$

\begin{tabular}{|c|c|c|c|c|}
\hline \multirow{2}{*}{ 要 } & \multirow{2}{*}{ 記号 } & \multirow{2}{*}{ 列潘 } & 水 & 潗 \\
\hline & & & 1 & 2 \\
\hline 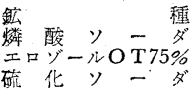 & $\begin{array}{l}\text { A } \\
\text { B } \\
\text { C } \\
\text { D }\end{array}$ & $\begin{array}{l}1 \\
2 \\
4 \\
7\end{array}$ & $\begin{array}{c}\mathrm{A}_{1} \\
2,000 \mathrm{~g} / \mathrm{t} \\
0 \mathrm{~g} / \mathrm{t} \\
2,000 \mathrm{~g} / \mathrm{t}\end{array}$ & $\begin{array}{c}\mathrm{A}_{2} \\
3,000 \mathrm{~g} / \mathrm{t} \\
20 \mathrm{~g} / \mathrm{t} \\
3,000 \mathrm{~g} / \mathrm{t}\end{array}$ \\
\hline
\end{tabular}

第 4表 わりつ溒

\begin{tabular}{|c|c|c|c|c|}
\hline 要因 & A & B & C & $\mathrm{D}$ \\
\hline $\begin{array}{r}1 \\
2 \\
3 \\
4 \\
5 \\
6 \\
7 \\
7 \\
{ }^{8}\end{array}$ & $\begin{array}{l}1 \\
1 \\
1 \\
1 \\
2 \\
2 \\
2 \\
2 \\
\mathrm{a}\end{array}$ & $\begin{array}{l}1 \\
1 \\
2 \\
2 \\
1 \\
1 \\
2 \\
2 \\
\text { b }\end{array}$ & $\begin{array}{l}1 \\
2 \\
1 \\
2 \\
1 \\
2 \\
1 \\
2 \\
\mathrm{c}\end{array}$ & $\begin{array}{r}1 \\
2 \\
2 \\
1 \\
2 \\
1 \\
1 \\
2 \\
\mathrm{abc}\end{array}$ \\
\hline
\end{tabular}

第 7 表，選鉱成績の推定値(硫化法)

\begin{tabular}{|c|c|c|c|c|c|c|c|}
\hline \multirow{2}{*}{ 鲐 } & \multirow{2}{*}{\multicolumn{2}{|c|}{ 種 }} & \multirow{2}{*}{$\begin{array}{l}\text { 鉱量 } \\
\text { (\%) }\end{array}$} & \multicolumn{2}{|c|}{ 品位 $(\%)$} & \multicolumn{2}{|c|}{ 実収率 $(\%)$} \\
\hline & & & & $\mathrm{Cu}$ & $\mathrm{Pb}$ & $\mathrm{Cu}$ & $\mathrm{Pb}$ \\
\hline 原 & & 躴 & 100.00 & 0.42 & 6.09 & 100.00 & 100.00 \\
\hline 銅 & 精 & 釷 & 1.40 & 12.00 & 12.00 & 40.00 & 2.76 \\
\hline 鈶 & 精 & 鈗 & 8.526 & 0.50 & 55.00 & 10.14 & 77.00 \\
\hline 尾 & & 鉣 & 90.074 & 0.23 & 1.37 & $\mid 49.86$ & 20.24 \\
\hline
\end{tabular}

第 8 表 浮選剤の添加量

\begin{tabular}{|c|c|c|c|c|c|}
\hline y & - - & & ダ & 灰 & $6,000 \mathrm{~g} /$ \\
\hline 第 & 二 燐 & 酸 & ソ & ダ & 2,000 \\
\hline 硫 & 化 & ソ & - & ダ & 2,500 \\
\hline$I$ & チル。 & $+*$ & $y+-$ & F & 100 \\
\hline A. & C. C. & \# & 404 & & 200 \\
\hline A. & C. C. & \# & 242 & & 100 \\
\hline 日 & 香 パ & 1 & ข & 晃 & 150 \\
\hline
\end{tabular}

第 9 表 実験の計画 $\left(\mathrm{L}_{8} 2^{7}\right)$ -

\begin{tabular}{|c|c|c|c|c|}
\hline \multirow{2}{*}{ 要 } & \multirow{2}{*}{ 記号 } & \multirow{2}{*}{ 列番 } & \multirow{2}{*}{$\frac{\text { 水 }}{1}$} & “準 \\
\hline & & & & 2 \\
\hline $\begin{array}{l}\text { メチル・ザンセ } \\
\text { ートカリ }\end{array}$ & A & 1 & $2,400 \mathrm{~g} / \mathrm{t}$ & $1,600 \mathrm{~g} / \mathrm{t}$ \\
\hline 橉酸ソダ- 灰 & $\begin{array}{l}\mathrm{B} \\
\mathrm{C}\end{array}$ & $\begin{array}{l}2 \\
4\end{array}$ & $\begin{array}{l}5,000 \mathrm{~g} / \mathrm{t} \\
2,400 \mathrm{~g} / \mathrm{t}\end{array}$ & $\begin{array}{l}3,000 \mathrm{~g} / \mathrm{t} \\
1,600 \mathrm{~g} / \mathrm{t}\end{array}$ \\
\hline 捕収剤の種類 & D & 5 & $\because 404$ & KHX \\
\hline 鉱種 & $E$ & 7 & $\mathrm{E}_{1}$ & $\mathrm{E}_{2}$ \\
\hline
\end{tabular}

第10表 わりつけ表

\begin{tabular}{|c|c|c|c|c|c|c|c|}
\hline \multirow{2}{*}{ No. 列䧽 } & A & B & C & D & $\mathrm{E}$ & \multicolumn{2}{|c|}{ データ } \\
\hline & 1 & 2 & 4 & 5 & 7 & & $\begin{array}{l}\mathrm{Pb} \\
\text { 品位 }\end{array}$ \\
\hline 1 & 1 & 1 & 1 & 1 & 1 & 87 & 30 \\
\hline 2 & 1 & 1 & 2 & 2 & 2 & 71 & 46 \\
\hline 3 & 1 & 2 & 1 & 1 & 2 & 72 & 31 \\
\hline 4 & 1 & 2 & 2 & 2 & 1 & 84 & 42 \\
\hline 5 & 2 & 1 & 1 & 2 & 2 & 68 & 45 \\
\hline 6 & 2 & 1 & 2 & 1 & 1 & 85 & 40 \\
\hline & 2 & 2 & 1 & 2 & 1 & 80 & 42 \\
\hline 8 & 2 & 2 & 2 & 1 & 2 & 73 & 34 \\
\hline
\end{tabular}


に示して洨る5゙。

\section{4. メチルザンセートによる 酸化鉛鉱の浮選試験}

一SH 基を有する有機化合物は重金属イオンと反応し てその塩を作ることが知られている。ザンセートは一S H基を有するので重金属イオンと反応して重金属ザンセ 一トを作る。鉣物粒子の表面に不溶性重金属ザンセート が生ずれば鉱物表面は踈水性になつて気泡に接着し，浮 選ができるようになる。硫化ソーダの代りにメチルザン セートを用いて硫酸鉛鉣を活性化して浮選を行なうこと について試験を実施した。

\section{$4 \cdot 1$ 粗鉱の浮選試験}

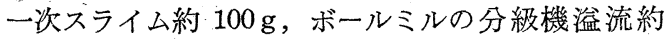
$400 \mathrm{~g}$ を混合して浮選試験を行なつた。実験の計画は第 9 10表，原鉣の組成は第11表，分散分析の結果の総括 表は第12表, 選鉱成績の推定值法第13表の通りである5。 ザンセート浮選で硫化物を除去した後硫酸鉛鉱の浮選を 行なつた。粗選浮鉱の $\mathrm{Pb}$ 品位及び $\mathrm{Pb}$ 実收率につい て分散分析を行なつたのが上記の表である。

第11表 試験原鉱の組成

\begin{tabular}{|c|c|c|c|c|c|c|c|}
\hline \multirow{2}{*}{$\begin{array}{l}\text { 実 験 } \\
\text { 年月日 }\end{array}$} & \multirow{2}{*}{ 種 } & \multicolumn{2}{|c|}{ 鉣 量 } & \multicolumn{2}{|c|}{ 品位 $(\%)$} & \multicolumn{2}{|c|}{ 分布率(\%) } \\
\hline & & g & $\%$ & $\begin{array}{c}\text { total } \\
\mathrm{Pb}\end{array}$ & $\mathrm{PbO}$ & $\begin{array}{c}\text { total } \\
\mathrm{Pb}\end{array}$ & $\mathrm{PbO}$ \\
\hline $\begin{array}{l}35.1 .8 \\
35.1 .9\end{array}$ & $\begin{array}{c}\mathbf{E}_{1} \\
\text { 分級機溢流 } \\
\text { 一次天ライム } \\
\mathbf{E}_{2} \\
\text { 分級機溢流 } \\
\text { 一次スライム }\end{array}$ & $\begin{array}{l}581.5 \\
472.0 \\
109.5 \\
529.4 \\
417.9 \\
111.5\end{array}$ & $\begin{array}{r}100.00 \\
81.17 \\
18.83 \\
100.00 \\
78.94 \\
21.06\end{array}$ & \begin{tabular}{|r|}
5.64 \\
5.32 \\
7.03 \\
7.24 \\
5.64 \\
13.26
\end{tabular} & \begin{tabular}{r|}
4.67 \\
4.29 \\
5.23 \\
6.47 \\
4.81 \\
12.67
\end{tabular} & $\begin{array}{r}100.00 \\
76.54 \\
23.46 \\
100.00 \\
61.45 \\
38.55\end{array}$ & $\begin{array}{r}100.00 \\
77.95 \\
22.05 \\
100.00 \\
58.73 \\
41.27\end{array}$ \\
\hline
\end{tabular}

第12表 分散分析の結果の総括表

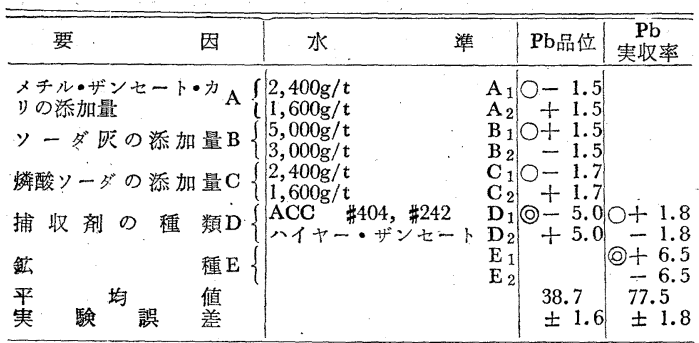

䚛考 ○性危険率 5\%，以危険率 1\% で有意。

第13表 最良条件と選鉝成績の期待值

\begin{tabular}{|c|c|c|c|}
\hline 因 & 鉱 種 & 粗選浮鉱 $\mathrm{Pb}$ 品位 & 粗選浮鉱 $\mathrm{Pb}$ 実収率 \\
\hline $\begin{array}{l}\mathrm{A}_{2} \mathrm{~B}_{2} \mathrm{C}_{2} \mathrm{D}_{1} \\
\mathrm{~A}_{2} \mathrm{~B}_{2} \mathrm{C}_{2} \mathrm{~J}_{2}\end{array}$ & $\begin{array}{l}\mathbf{E}_{1} \\
\mathbf{E}_{2} \\
\mathbf{E}_{1} \\
\mathbf{E}_{2}\end{array}$ & $\begin{array}{l}35.4 \\
35.4 \\
45.4 \\
45.4\end{array}$ & $\begin{array}{l}85.8 \\
72.8 \\
82.2 \\
69.2\end{array}$ \\
\hline
\end{tabular}

\section{$4 \cdot 2$ 酸化鉛鉱の浮選の前に硫化物を除く場合と除かな い場合の比較}

これまでの試験は酸化鉛鉱の浮選の前に硫化物を除い て行なつたが硫化物を除かない場合との比較は第14表の 通りである。
第14表 酸化鉛釯の浮選の前に硫化物を除 いた場合と除かない場合との比較

\begin{tabular}{|c|c|c|c|}
\hline 鉱 。 & 区 & $\mathrm{Pb}$ 品位 & $\mathrm{Pb}$ ，実収率 \\
\hline 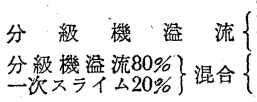 & $\begin{array}{l}\text { 除いた場合 } \\
\text { 除かない場合 } \\
\text { 除いた場合 } \\
\text { 除かない場合 }\end{array}$ & $\begin{array}{l}56.1 \\
43.1 \\
53.0 \\
45.0\end{array}$ & $\begin{array}{l}80.4 \\
65.4 \\
76.3 \\
61.0\end{array}$ \\
\hline
\end{tabular}

\section{$4 \cdot 3$ メチルザンセート添加後の攪拌時間の比較}

試験の結果は第 15～16 表の通りである。

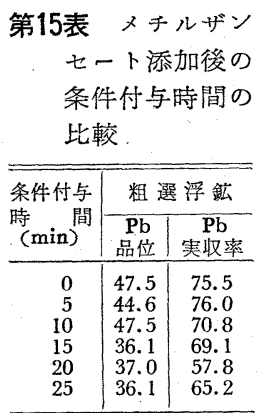

第16表 酸化鉛鉱の浮選におけ

\begin{tabular}{|c|c|c|c|c|}
\hline \multicolumn{3}{|c|}{$\begin{array}{l}\text { 浮選鼡添加後の条件付 } \\
\text { (min) }\end{array}$} & \multicolumn{2}{|c|}{ 精選浮鉣 } \\
\hline 燐 & $\mid \begin{array}{l}\text { メチルザ } \\
\text { ンセート }\end{array}$ & 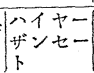 & $\begin{array}{l}\mathrm{Pb} \\
\text { 品位 } \\
(\%)\end{array}$ & $\begin{array}{l}\mathrm{Pb} \\
\text { 実収率 } \\
(\%)\end{array}$ \\
\hline 1 & 1 & 1 & 65.5 & 76.3 \\
\hline 1 & 5 & 1 & 63.4 & 73.5 \\
\hline 5 & 1 & 1 & 62.2 & 79.5 \\
\hline 5 & 1 & 1 & 63.4 & 80.2 \\
\hline
\end{tabular}

$4 \cdot 4$ 第 2 燐酸ソーダをボールミルに添加した場合と酸 化鉛鉱浮選の前に添加した場合の比較

第17表 銅粗精鉣中の $\mathrm{Pb}$ 損失率の比較

\begin{tabular}{|c|c|c|c|c|c|c|c|c|}
\hline \multirow{2}{*}{ 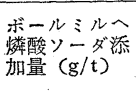 } & \multicolumn{3}{|c|}{ 浮選剤添加量 $(\mathrm{g} / \mathrm{t})$} & \multirow{2}{*}{$\begin{array}{l}\text { 鉱量 } \\
\text { (\%) }\end{array}$} & \multicolumn{2}{|c|}{ 品位 $(\%)$} & \multicolumn{2}{|c|}{ 損失率 $(\%)$} \\
\hline & Y゙- & $\mathrm{KHX}$ & $\begin{array}{r}\text { 日潐 } \\
\$ 750 \\
\end{array}$ & & $\begin{array}{c}\text { total } \\
\mathrm{Pb}\end{array}$ & $\mathrm{PbO}$ & $\begin{array}{c}\text { total } \\
\mathrm{Pb}\end{array}$ & $\mathrm{PbO}$ \\
\hline $\begin{array}{c}2,000 \\
1,000 \\
1,000 \\
0\end{array}$ & & $\begin{array}{r}100 \\
100 \\
60 \\
100\end{array}$ & $\begin{array}{l}30 \\
30 \\
30 \\
30\end{array}$ & $\begin{array}{l}4.7 \\
2.9 \\
1.5 \\
1.0\end{array}$ & $\begin{array}{l}47.7 \\
41.2 \\
29.5 \\
16.8\end{array}$ & $\begin{array}{r}44.6 \\
36.2 \\
21.3 \\
4.9\end{array}$ & $\begin{array}{r}43.3 \\
23.8 \\
8.9 \\
3.2\end{array}$ & $\begin{array}{r}46.7 \\
25.9 \\
7.9 \\
1.2\end{array}$ \\
\hline
\end{tabular}

4.5 粉末メチルザンセートと液体メチルザンセートの 比較

第18表 メチル・ザンセートカリ(粉末)とメチルザ ンセート・ナトリウム(液体)の比較

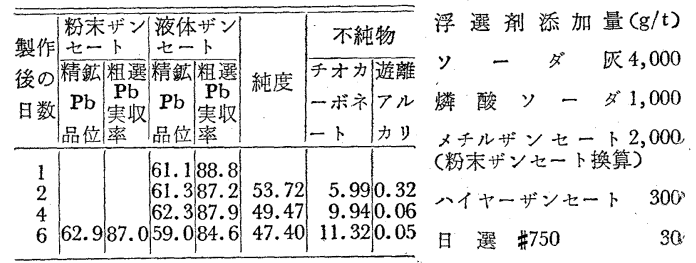

$4 \cdot 6$ 活性剤としての各種ザンセートの比較 第19表 ザンセートの比較

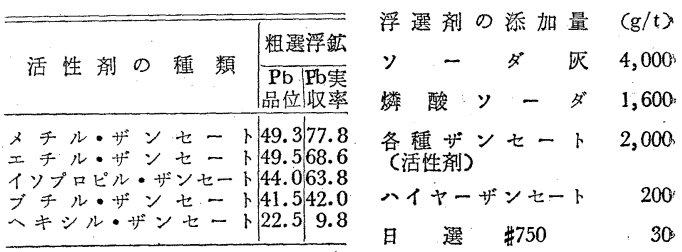

\section{$4 \cdot 7$ 予想成績}

予想成績は第20〜21表の通りで，現場操業の場合には 


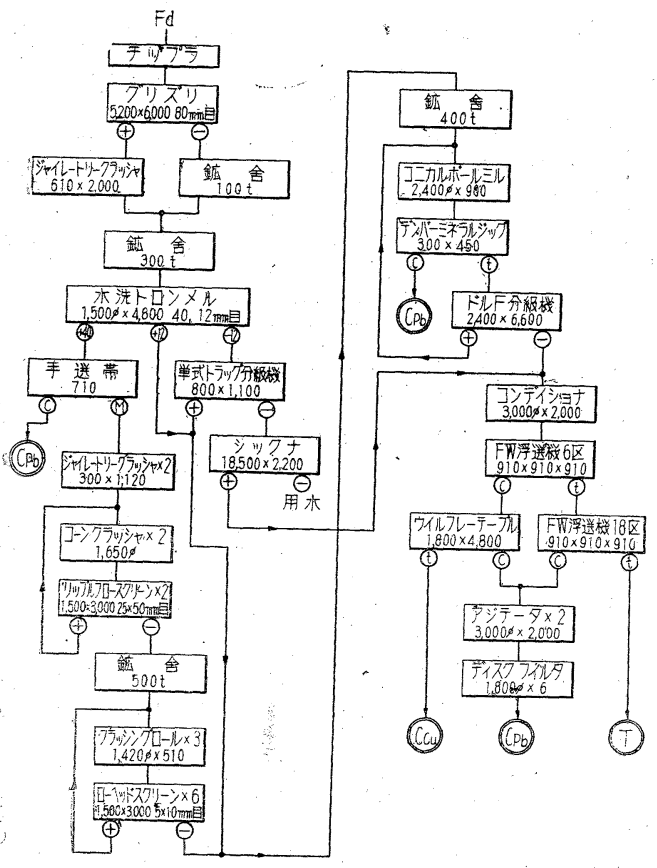

受入, 破䂗は銅系々共通 (昭和 36 年 1 月)

第1図 尾去沢選鉣工場酸化鉛系系統図

手選精鉱，ジツガ一精鉱を採取するから実收率は高くな る。

第20表 予想選鉱成績 第21表 浮選剤添加量 $(\mathrm{g} / \mathrm{t})$

\begin{tabular}{|c|c|c|c|c|c|c|c|}
\hline \multirow{2}{*}{ 鈆種 } & \multirow{2}{*}{$\begin{array}{l}\text { 鉣量 } \\
(\%)\end{array}$} & \multicolumn{2}{|c|}{ 品位 $(\%)$} & \multicolumn{2}{|c|}{ 実收率(\%) } & ソ - ダ 灰 5 & 5,00 \\
\hline & & $\mathrm{Cu}$ & $\mathrm{Pb}$ & $\mathrm{Cu}$ & & 第 2 燐 酸 & 1,000 \\
\hline 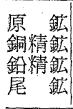 & $\begin{array}{l}0 \\
2 \\
6\end{array}$ & $\begin{array}{l}0.35 \\
5.00 \\
0.50 \\
0.23\end{array}$ & $\begin{array}{r}4.60 \\
12.00 \\
52.00 \\
1.11\end{array}$ & & & $\begin{array}{l}\text { エチル・ザンセート } \\
\text { ハイナー・ザンセート }\end{array}$ & 4,000 \\
\hline
\end{tabular}

\section{5. 現 場 操 業}

第22表 酸化鉛鉱浮選の各部分の分析品位

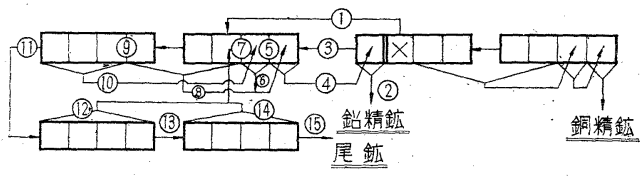

\begin{tabular}{|c|c|c|c|c|c|c|c|c|}
\hline 番 号 & 1 & & 2 & 3 & 4 & 5 & 6 & 7 \\
\hline $\begin{array}{l}\text { total } \mathrm{Pb} \\
\mathrm{PbO} \\
\text { insol }\end{array}$ & $\begin{array}{r}4.50 \\
3.35 \\
70.96\end{array}$ & & $\begin{array}{l}51.51 \\
44.32 \\
12.38\end{array}$ & $\begin{array}{l}16.31 \\
13.65 \\
44.00\end{array}$ & $\begin{array}{l}47.50 \\
43.91 \\
14.52\end{array}$ & $\begin{array}{l}12.93 \\
10.63 \\
48.82\end{array}$ & $\begin{array}{l}24.66 \\
22.26 \\
37.66\end{array}$ & $\begin{array}{r}4.76 \\
3.20 \\
58.26\end{array}$ \\
\hline 品位 & 8 & 9 & 10 & 11 & 12 & 13 & 14 & 15 \\
\hline $\begin{array}{l}\text { total } \mathrm{Pb} \\
\mathrm{PbO} \\
\text { insol }\end{array}$ & $\begin{array}{l}41.55 \\
37.76 \\
19.34\end{array}$ & $\begin{array}{r}1.53 \\
0.29 \\
73.10\end{array}$ & \begin{tabular}{l|l}
3 & 16.42 \\
9 & 13.75 \\
0 & 46.72
\end{tabular} & $\begin{array}{r}1.25 \\
0.25 \\
74.50\end{array}$ & $\begin{array}{r}3.43 \\
2.48 \\
63.34\end{array}$ & $\begin{array}{r}0.90 \\
0.08 \\
74.50\end{array}$ & $\begin{array}{r}2.83 \\
1.64 \\
62.92\end{array}$ & $\begin{array}{r}0.86 \\
0.08 \\
74.70\end{array}$ \\
\hline
\end{tabular}

時間は30分程度と考えられるので，スカベンジャーのフ ロスは給鉱の区に繰返す等実收率の向上を主眼として票 統を計画した。

\section{$5 \cdot 2$ 選鉱成績}

酸化鉛鉱の浮選の各部分の分析品位注第22表に示して あるが，これは原鉱の変化により相当変動する。

昭和 35 年 11 月より昭和 36 年 3 月の間の選鉱成績法第 23 表の通りで大体所期の成績が得られた。

第23表において浮選原鉱に対する実收率は第24表の通 りである。

\section{$5 \cdot 3$ 将来の問題点}

(1)，液体メチルザンセートは夏季には分解が速くな るのでこの対策を講じなければならない。冬季汇频作 後大体 3 日間以内に使用するようにしているが，夏季に はザンセートの分解を遅らせるため冷涷機で冷却する予 定である。

（2）原鉱組成とくに $\mathrm{PbO} / \mathrm{Pb}$ の比の変化によって 選鉱成績が大きく変動し，このため一定した選鉱成績を

\section{$5 \cdot 1$ 操業系統}

昭和35年10月より一次スライムを除いた原 鉱について試験操業を実施し，同年11月より 一次スライムの混合処理を始めた。操業系統 は第1図の通りである。浮選の系統を計面す るに際し特に留意した点は次の通りであ る。

（1）銅精釷の中に酸化鉛釷物が混入しな いように精選回数を 2 回にした。

（2）橉酸ソーダおよびメチルザンセート 添加後の攪抖時間を調節するため，デンバー 浮選機をコンディショナーに使い粯拌時間の 影響を検討した。

（3）・メチルザンセートが有効に作用する

第23表 選鉱成績（昭和35年11月～昭和36年 1 月）

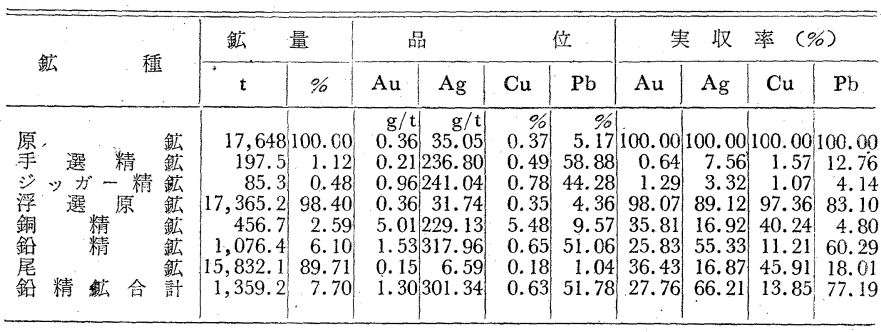

第 24 表

\begin{tabular}{|c|c|c|c|c|}
\hline \multirow{2}{*}{ 鉱 種 } & \multicolumn{2}{|c|}{ 実 收 } & \multicolumn{2}{|c|}{ 率 (9ó) } \\
\hline & $\mathrm{Au}$ & $\mathrm{Ag}$ & $\mathrm{Cu}$ & $\mathrm{Pb}$ \\
\hline 浮選銅精釷 & 36.52 & 18.98 & 41.33 & 5.77 \\
\hline 浮選鉛精鉱 & 26.34 & 62.09 & 11.51 & 72.55 \\
\hline
\end{tabular}

第25表 浮選剤使用量 $(\mathrm{g} / \mathrm{t})$

\begin{tabular}{|c|c|c|}
\hline$y$ - 名灰 & 4,455岡田起泡剂\#750 & \\
\hline 燐酸 ソーダ & 841 ヘイヤーザンセート & \\
\hline フォオソクレゾー & 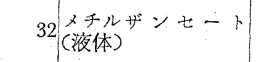 & 3,63 \\
\hline 日香パイン10号 & 34 & \\
\hline
\end{tabular}


期待することは困難であるが，尾鉱中の $\mathrm{PbO}$ 品位が上 昱しないように管理している。尾鉱中の $\mathrm{PbO}$ 品位は $0.1 \%$ 前後になつている。 PbS として分析される中に は方鉛鉣以外にビーバーライトも含まれ，尾鉱中の $\mathrm{Pb}$ の大部分はこれらの鋝物よりなつている。尾鉱 $\mathrm{Pb}$ 品 位をさらに低下させることを研究する予定である。

（3）精鈗品位をさらに上昇させるため分散剤の研究 学行なう予定である。

\section{6. 総 括}

酸化鉛鉣の浮選法の中，石けん浮選法，硫化法，メチ ルザンセートで活性化する方法について検討した結果， メチルザンセートで活性化する方法で操業を始め，大体 所期の目的を達することが出来た。

（1）当所の酸化鉛鉱の鉛鉣物は主として硫酸鉛鉣で ビーバーライト $\left[\mathrm{Pb}(\mathrm{Cu}, \mathrm{Fe}, \mathrm{Al})_{3}\left(\mathrm{SO}_{4}\right)_{2}(\mathrm{OH})_{6}\right]$ や方鉛 鉱を伴なつている。この外黄銅鉱，黄鉄鉱等の有価鉱物 も存在している。ビーバーライトは組成分析では $\mathrm{PbS}$ として分析され，原鉱中の非硫化鉛/鉛の比は $0.7 〜 0.8$ である。

（2）酸化鉛鉱中のプライマリースライムの量は粗鉱 の $13 \%$ ，品位は粗鉱の 1.3 倍で含有分布率は約 $17 \%$ で

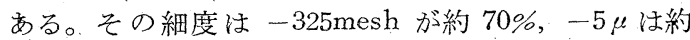

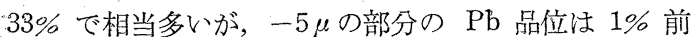
後で -325 mesh $+5 \mu$ の部分に $\mathrm{Pb}$ が約 $65 \%$ 分布し ている。

（3）石け儿浮選法で酸化鉛鉱を処理すると，プライ マリースライム注処理出来ないので $\mathrm{Pb}$ 実収率は比較 的低く, 昭和 34 年 4 月より昭和35年 3 月の閒の選鉱成績 は原鉣 $\mathrm{Pb}$ 品位 $6.64 \%$ ，精鈗 $\mathrm{Pb}$ 品位 $54.73 \%, \mathrm{~Pb}$ 実収 率 $55.4 \%$ であつた。また本法では原鉱中に含有される 硫化物 (黄銅鉱, 方鉛鉱) の実収率はきわめて低く，そ れに伴なつている金，銀の実収率も低かつた。

（4）硫化ソーダで硫酸鉛鉱を活性して浮選を行なう 場合には，まずソーダ灰で $\mathrm{pH}$ を 7 程度に調整して硫化 銅鉱物，方鉛鉱，黄鉄鉣などの硫化物をザンセート浮選 で採取した後，第二燐酸ソーダ，硫化ソ一ダを添加して 硫酸鉛鉱を活性し，捕収剤としてエロフロート \#404， およびエロフロート\#242 を添加して浮選を行なうこと ができる。

本法によればプライマリースライムの浮選も可能で,

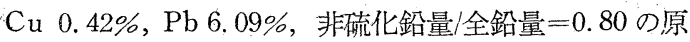
鉱より $12 \% \mathrm{Cu}$ の銅精鉱，55\% $\mathrm{Pb}$ の鉛精鉱が実収率

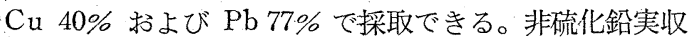
率は $90 \%$ が期蒔できるが， $\mathrm{PbS}$ 実收率は 18\% 程度で ある。このため $\mathrm{Pb}$ 実収率は $80 \%$ 以上期待することは 出来ない。
（5）メチルザンセートで硫酸鉛鉱を活性化して浮選 を行なう場合にはまずソーダ扊で $\mathrm{pH}$ を 6.4 亿調整して 硫化銅鉱物, 方鉛鉱, 黄鉄鉱などの硫化物をザンセート浮 選で採取した後，第二燐酸ソーダ，メチルザンセートを 添加して硫酸鉛鉱を活性化し，捕収剤としてハイヤーザ ンセート，起泡剤として日選 \#750を加えて浮選を行な うことができる。本法によれば硫化法と同様の選鉱成績 が期待でき, $\mathrm{Cu} 0.35 \%, \mathrm{~Pb} 4.60 \%$, 非硫化鉛量/全鉛 量 $=0.75$ の原鉱より $5 \% \mathrm{Cu}$ の銅精鉱， $52 \% \mathrm{~Pb}$ の鉊 精鉱が実收率 $\mathrm{Cu} \mathrm{30 \% ，および} \mathrm{Pb} 72.35 \%$ で採取出来 る。浮選剤の費用は硫化法より安い。

（6）メチルザンセートで硫酸鉛鉱を活性化して浮選 を行なう場合，留意す心゙き事項は次のようである。

1）硫化法と異なつて捕収剤はハイヤーザンセート でよいが起泡剂は起泡力の強い日選 \#750を使つた方が $\mathrm{Pb}$ 実收率は高いようである。

2）酸化鉛鉱の浮選の前に硫化物を除いた方がメチ ルザンセートの消費量が少なくなり $\mathrm{Pb}$ 実収率，精鉱 品位が向上する。硫化物を除かない場合にメチルザンセ 一トの添加量を増加させなければ精鉱品位， $\mathrm{Pb}$ 実收率 其に低下する。これは硫化物がメチルザンセートを消費 するためと思われる。

3) メチルザンセート添加後の攪汼時間は $5 \mathrm{~min}$ 位 で充分で，長く攪抖すれば害収率が低下する傾向があ る。すなわちメチルザンセートが有効に作用する時閒は 比較的短加。

4) 燐酸ソーダは硫化物浮選が終つた後で添加した 方がよい。

5) 粉末メチルザンセートカリと液体メチルザンセ 一トナトリウムとはほぼ同様の活性効果がある。液体メ チルザンセート, ナトリウムの方が安いので経済的に有 利であるが，分解が早いので使用に際しては注意しなけ ればならない。

6 ）酸化鉛鉱の活性剤として各種ザンセートの比較 試験を行なつたところ,メチルザンセートが最も有効で あつた。

（7）原鉱の非硫化鉊量/全鉛量の比の変化によつて 選鉱成績の変動は大きい。

\section{参考文 献}

1) A. M. Gaudin : Flotation, 1957 pp. 251 253, Pp. 460 467.

2) Taggart: Handbook of Mineral Dressing, January, $1948 \mathrm{pp}$. 12-11, pp. 12-35 36, pp. 12-120.

3) F. B. Michell: The Practice of Mineral Dressing, $1950 \mathrm{pp}$ 143 147.

4) K. L. Sutherland and I. W. Wark, Principles of Flotasion, 1955 pp. 80 , pp. 95 , pp. $164 \sim 167$, pp. $388 \sim 390$.

5) 田口玄一：実験計画法上，䁒和32年12月 1 目 pp. 38 96; pp. 227 $\sim 248$ 